\title{
What Affects a Taiwan Fund Company's Operating Performance? An Analysis on Market Share
}

\author{
Feng-Huei Chang1, Yeong-Jia Goo² \\ ${ }^{1}$ Department of Insurance and Finance Management, Chihlee University of Technology, Taiwan \\ ${ }^{2}$ Department of Business Administration, National Taipei University, Taiwan \\ Email: fenghuei@mail.chihlee.edu.tw, goo@mail.ntpu.edu.tw
}

How to cite this paper: Chang, F.-H. and Goo, Y.-J. (2017) What Affects a Taiwan Fund Company's Operating Performance? An Analysis on Market Share. Theoretical Economics Letters, 7, 1282-1291. https://doi.org/10.4236/tel.2017.75087

Received: April 19, 2017

Accepted: July 29, 2017

Published: August 1, 2017

Copyright @ 2017 by authors and Scientific Research Publishing Inc. This work is licensed under the Creative Commons Attribution International License (CC BY 4.0).

http://creativecommons.org/licenses/by/4.0/ c) (i) Open Access

\begin{abstract}
This study aims to explore the factors that affect the operating performance of 37 Taiwan fund companies by examining monthly data from open-end domestic equity funds and balanced funds from January 2001 to April 2013. The market share of domestic equity funds and balanced funds is used as the proxy variable to measure a company's operating performance. The results show that there is a significant difference in market share between foreign and domestic fund companies. The age of the fund company, the average turnover rate, and the number of people subscribing for dollar-cost-averaging investment plans are found to be positively related to a company's market share, while the average rates of transaction cost and management fee are negatively related to the market share. We also find that star funds have a significantly positive effect on the market share of a mutual fund company.
\end{abstract}

\section{Keywords}

Mutual Fund, Fund Company, Operating Performance, Market Share

\section{Introduction}

Mutual fund companies have become one of the fastest-growing industries in Taiwan's financial service sector over the past 20 years, since the government's policy of opening the capital market in 1992 and allowing the opening of new securities investment trust enterprises (SITEs). Statistics from the Securities Investment Trust \& Consulting Association (SITCA) show that as of the end of June 2010 there were a total of 535 various onshore, open-end mutual funds, with total assets reaching NTD 1,815,662 million. The number of SITEs has increased from four in 1990 to 39 in 2011, while the number of workers they 
employ has grown from 2988 in 2002 to 3819 in 2011.

In recent years, fund companies have undergone multifaceted change within the industry, a bond fund crisis in 2004, global financial crises, product innovation, mergers and acquisitions involving foreign capital, and the expectation of future competition from China. Thus, fund companies will not be able to survive in such an environment by just being supported by their own syndicate. How a fund company develops its own management strategy is becoming more and more important for its future growth. This question motivates us to explore the factors that affect operating performance of Taiwan fund companies.

The purchase decisions of mutual-fund investors are influenced by salient, attention-grabbing information. They buy funds that attract their attention through exceptional performance, marketing, or advertising (see [1]). Thus, the more fund flows increase, the higher the operating performance of a fund company will be. A fund company would like to maximize its market share because its revenue is a function of assets under management. Previous research related to the market share of fund companies is scarce, with only a few notable exceptions. Reference [2] shows that fund families with larger marginal benefits increasing their scale do subsequently gain market share at the expense of their rivals. However, this effect diminishes as the fund family gets older, perhaps as a consequence of imitation. Reference [3] analyzes the determinants that drive market share in the mutual-fund industry. Reference [4] shows that product proliferation is a well-documented phenomenon in industrial organization and is widely understood as a strategy aimed at preserving market share. Reference [5] finds that price competition and product differentiation are both effective strategies for obtaining market share. Reference [6] uses market share changes instead of fractional flows as the dependent variable to study the fund flowperformance relation. They show that market shares offer an alternative specification for flow that is more resilient to heterogeneity.

This paper focuses on the study of fund companies' operating performance. Market share is used as the proxy variable for the operating performance of fund companies. Reference [7] reports that in the U.S. mutual-fund industry multiproduct fund complexes with large economic scale are able to realize some efficiency gains by increasing their asset sizes. This suggests that market share can be represented as a key performance index for a fund company to survive in the asset-management industry. Further, [6] suggests that market share can be a better alternative than the fractional flow model in the study of fund flowperformance relation. In this context, four main research questions are raised in the present article. First, we would like to investigate whether domestic or foreign fund companies lead to different market shares of non-bond funds. Second, we would like to examine whether or not fund performance affects fund companies' market shares. Third, we want to test whether fee characteristics have an impact on the market share of fund companies. Finally, we inspect whether the constitution of customer portfolios influences the market share of fund companies.

Prior studies on Taiwan mutual funds mostly concentrate on the many facets 
of fund performance (see, e.g., [8]; [9]; [10]) and find that the work at the fund corporate level is relatively limited. This paper empirically investigates the factors that affect the operating performance of 37 Taiwan fund companies by examining monthly data of open-end domestic equity funds and balanced funds from January 2001 to April 2013. The market share of domestic equity funds and balanced funds is used as the proxy variable to measure a company's operating performance. The results show that there is a significant difference in market share between foreign and domestic fund companies. The age of a fund company, the average turnover rate, and the number of people subscribing to dollarcost-averaging investment plans are found to be positively related to a company' $s$ market share, while the average rates of transaction costs and management fees are negatively related to the market share. We also find that star funds have a significantly positive effect on the market share of a mutual fund company. We make two contributions in this article. First, the study makes up for the deficiencies in the current academic literature on the level of the fund complex and serves as a reference for subsequent academic research. Second, in addition to assessing the effect of fees, we examine in our empirical study the non-price competition within the fund industry (i.e., customer structure and company and product characteristics).

The remainder of this paper is arranged as follows. Section 2 introduces the related literature and hypotheses, Section 3 describes the data and methodology, Section 4 explains the empirical results, and Section 5 presents the discussion and conclusion.

\section{Literature Review and Hypothesis}

Research at the level of fund companies has started to draw attention only recently. The majority of previous studies on mutual funds have been at the individual fund level and have focused on various aspects of their performance (see, e.g., [11]-[18]). Previous studies at the fund-company level have included [3], who investigates the determinants of mutual-fund initiations; [19], who provides a model that explains what determines the decision to set up new funds within existing categories (i.e., fund proliferation) and to enter new categories (i.e., category proliferation) in the mutual-fund industry. Reference [20] investigates how industry structure affects mutual-fund behavior and shows that fund families actively exploit heterogeneity among funds. Reference [21] examines whether fund families seek to generate star funds by increasing the cross-fund return variance or the number of funds in the family. Reference [22] shows that fund families actively pursue a direct family strategy of enhancing the performance of high-value funds, which are more likely to increase overall family profits, at the expense of other, lower-value funds. Reference [23] investigates the presence of spillover effects of marketing in mutual-fund families, and they find that funds with high marketing expenses generate spillover effects and enhance cash inflows to family members with low marketing expenses. Reference [24] analyzes the family level determinants of fund-incubation decisions and finds evidence 
that incubation is used by families to speciously enhance performance and thereby increase flows.

Studies on a fund company's market share have started to gain prominence only recently. Reference [2] measures the inter-firm differences in economies of scale and examines how they affect the subsequent evolution of the market share distribution in the money-market mutual-fund industry. The results show that firms whose capabilities give them greater economies of scale than their competitors in the same industry subsequently gain market share at the expense of those competitors. And this effect of firm specific portfolio selection-based scale economies on relative market share diminishes as firms age. Reference [3] finds that more funds are opened by families with star funds. This suggests that families want to exploit their reputation as excellent performers by expanding their product line. Reference [4] examines how fund families respond to growth in assets under management. They find evidence that family growth, especially for the dominant large families, is mainly associated with the addition of new funds instead of an expanded scope of activities for existing funds. In addition, [5] reports that investors pay attention to fees in their asset deployment decision across fund family. They find that families have higher market share when they charge lower objective-adjusted fees relative to other families and that families whose expense ratios decline with fund size also have higher market share. Furthermore, [6] shows that using market share changes instead of fractional flows as the dependent variable is a better alternative to measure fund flow-performance relation. Their results indicate that investors first decide how much to invest and then determine how to split it up-a sequence more in line with a market share than a fractional flow model.

Based on the foregoing literature review and research context, four working hypotheses are examined as follows:

H1: Whether or not a fund company belongs to a domestic fund company or a foreign fund company is likely to affect its market share $\left(\beta_{1} \neq 0\right)$.

$\mathrm{H} 2$ : If a fund company has at least one top-tier performer (top 10 for domestic equity funds or top 5 for balanced funds), its market share is more likely to increase $\left(\beta_{7}>0, \beta_{8}>0\right)$ (see [3]).

H3: The fee structure (the fee rate of transaction cost or management fee) has a negative effect on its fund company's market share $\left(\beta_{5}<0, \beta_{6}<0\right)$ (see [1] and [5]).

H4: The number of people subscribing to a dollar-cost-averaging investment plan (the constitution of the customer's portfolio) positively influences a company's market share $\left(\beta_{9}>0\right)$.

\section{Data and Methodology}

This paper studies the 37 domestic fund companies that issued open-end domestic equity funds and balanced funds between January 2001 and April 2013. The types of funds include Common Equity Funds, Medium-Small Capital Funds, High-Tech Funds, Value-Stock Funds, Theme Funds, Taiwan Enterprise 
Funds, OTC Equity Funds, and Common Equity-Balanced Funds, as well as Value-Balanced Funds. Regression analysis on panel data and a surviorship bias free sample (as defined in [25]) are employed to analyze the relation between the market share of fund companies and the related variables. We use the market share of domestic equity funds and balanced funds as the proxy variable for a company's operating performance. The samples selected for this study include fund companies, domestic equity funds, and balanced funds that were existent during the duration of the study period. The research data include monthly data on each fund, and each fund has up to 148 months of rate-of-return data. Funds with less than 148 months of data are also included in the study sample, and thus there is a total of 169 open-end equity funds and 25 balanced-equity funds in the resulting data sample. In addition to the monthly rate of return on individual funds, the data sample also includes fund size, company age, fund age, fund expenses, portfolio turnover rate, and the number of people subscribing for dollar-cost-averaging investment plan each month. All the data samples are taken from the Taiwan Economic Journal (TEJ) databank and the official Website of each fund company. The empirical analysis model is as follows:

$$
\begin{aligned}
M S_{i, t}= & \beta_{0}+\beta_{1} F D_{i, t}+\beta_{2} C A G E_{i, t}+\beta_{3} F A G E_{i, t}+\beta_{4} T N O V R_{i, t}+\beta_{5} F E E 1_{i, t} \\
& +\beta_{6} F E E 2_{i, t}+\beta_{7} S T A R S 1_{i, t}+\beta_{8} S T A R B 1_{i, t}+\beta_{9} C T M R_{i, t}+\varepsilon_{i, \varepsilon}
\end{aligned}
$$

The definitions of the variables in the formula above are shown below:

$M S_{i, t}$ Market share of the fund company's domestic equity funds and balanced funds (total size of domestic equity funds and balanced funds under management divided by total assets of a fund company).

$F D_{i, t}$ Dummy variable, domestic fund companies are set to 0 , foreign fund companies are set to 1 .

$C A G E_{i, i}$ The age of a fund company.

$F A G E_{i, i}$ Longest fund age of a fund company (fund age is the number of years since the fund's inception).

$T N O V R_{i, t}$ Average turnover rate of a fund portfolio (the average of the "buy" and "sell" turnover rate).

$F E E 1_{i, i}$ Average transaction costs (transaction fees and transaction taxes) as a percentage of total expenses.

$F E E 2_{i, i}$ : Average management fees (management fees, custodial fees, guarantee fees, and other expenses) as a percentage of total expenses.

STARS $_{i, t}$ Dummy variable-fund companies with domestic equity funds ranked among the top 10 in fund performance at month $t$ (based on the year-to-date return ranking of each fund) are set to 1; otherwise, they are set to 0 .

$S T A R B 1_{i, i}$ Dummy variable-fund companies with balanced funds ranked among the top 5 in fund performance (based on the year-to-date return ranking of each fund) are set to 1 ; otherwise, they are set to 0 .

$C T M R 2_{i, t}$ The number of customers subscribing to dollar-cost-averaging investment plans each month.

$C T M R 1_{i, t}$ The number of customers subscribing to lump sum investment. 
Following [22], a fund's year-to-date return (the return of the fund since January of the current year) was used as a performance measure, and funds with less than 6 months of return history were removed. This was because influential fund-listing providers such as Morningstar and much of the financial press normally report fund performances in terms of rudimentary performance measures such as historical returns, return rankings relative to other funds with a similar objective, and market-adjusted returns.

\section{Empirical Results}

Table 1 lists the descriptive statistics of the study sample. As can be seen from Table 1, during the duration of the study period, from January 2001 to April 2013, the size of the funds managed by the 37 fund companies ranges from a minimum of about 118 million to a maximum of nearly 80 billion Taiwan dollars. The number of customers with dollar-cost-averaging investment plans ranges from a minimum of five people, and at most over 200,000 people. The average age of the domestic equity funds and balanced funds managed by the fund companies was 10.58 years, with the shortest being 0.12 years and the longest being nearly 27 years. The average portfolio turnover rate was $28 \%$, with the lowest being -0.04 and the highest being $278 \%$. The average transaction costs (fees and transaction taxes) as a percentage of total expenses were $46 \%$, while the average of the management fees (management fees, custodial fees, guarantee fees, and other expenses) as a percentage of total expenses was 54\%. The average age of fund companies was 11.37 years, with the shortest being 0.1 years and the longest being nearly 30 years. The average market share of fund companies was $2.9 \%$, with the lowest being $0.04 \%$ and the highest being $15.8 \%$.

Table 1. Descriptive statistics of the study sample.

\begin{tabular}{cccccc}
\hline Variable & $\begin{array}{c}\text { Number of } \\
\text { Samples }\end{array}$ & Mean & $\begin{array}{c}\text { Standard } \\
\text { Deviation }\end{array}$ & Minimum & Maximum \\
\hline COM $^{\mathrm{a}}$ & 5080 & 22.84 & 13.72 & 1.00 & 48.00 \\
COMTNA $^{\mathrm{b}}$ & 5080 & $8,514,237.00$ & $10,332,769.00$ & $118,691.00$ & $79,622,207.00$ \\
CTMR & 5080 & $27,630.99$ & $35,167.56$ & 5.00 & $209,887.00$ \\
FAGE & 5080 & 10.58 & 5.45 & 0.12 & 26.95 \\
TNOVR & 5080 & 0.28 & 0.25 & -0.04 & 2.78 \\
FEE1 & 5080 & 0.46 & 0.16 & 0.00 & 1.00 \\
FEE2 & 5080 & 0.54 & 0.16 & 0.00 & 1.00 \\
DATE1 & 5080 & $200,693.16$ & 353.83 & $200,101.00$ & $201,304.00$ \\
CAGE1 & 5080 & 11.37 & 5.74 & 0.10 & 29.92 \\
STARS1 & 5080 & 0.20 & 0.40 & 0.00 & 1.00 \\
STARB1 & 5080 & 0.13 & 0.34 & 0.00 & 1.00 \\
MS ${ }^{c}$ & 5080 & 2.90 & 3.29 & 0.04 & 15.80 \\
\hline
\end{tabular}

a The number of fund companies; ${ }^{b}$ Units (in thousands) of total management assets of a fund company; ${ }^{c} U$ nits (\%). 
Table 2 is a comparison table of the empirical results from the regression analysis. This study compares the results from the pooling regression, the method of [26], and GMM regression analysis. As can be seen from the table, the regression parameter estimate results from the pooling regression, the method of [26] and GMM regression analysis are rather consistent. Except for the variable that represents the age of a fund company, all of the estimated coefficients of the other variables are statistically significant and support the hypotheses.

The empirical results in Table 2 show that almost all of the variables are higher than the 5\% significance level. Except for the variables that represent domestic or foreign fund companies, the longest fund age, the average transaction costs as a percentage of total expenses, and the average management fee as a percentage of total expenses-which have negative regression parameter estimates-the remaining variables all have positive regression parameter estimates. Among them, the dummy variable FD is significantly negative, which means that the market share of foreign fund companies on average is $0.67 \%$ lower than the market share of domestic fund companies.

As shown in Table 2, the age of a fund company (CAGE), has a positive impact on scale and market share, which indicates that longer-established fund companies have a larger market share. It is worth noting that the longest fund age of the fund companies (FAGE) shows a significantly negative relation with market share, which means that on average a fund company's oldest fund may not enhance the company's market share. In addition, the average transaction costs as a percentage of total expenses, and the average management fee as a percentage of total expenses, are significantly negative, indicating that high

Table 2. Regression analysis results.

\begin{tabular}{|c|c|c|c|c|c|c|}
\hline \multicolumn{3}{|c|}{ A. Pooled Regression } & \multicolumn{2}{|c|}{$\begin{array}{l}\text { B. Fama-MacBeth (1973) } \\
\text { Regression Analysis }\end{array}$} & \multicolumn{2}{|c|}{$\begin{array}{l}\text { C. System GMM } \\
\text { Regressions }\end{array}$} \\
\hline $\begin{array}{l}\text { Variable } \\
\text { Name }\end{array}$ & $\begin{array}{l}\text { Parameter } \\
\text { Estimates }\end{array}$ & $P$-Value & $\begin{array}{l}\text { Parameter } \\
\text { Estimates }\end{array}$ & $P$-Value & $\begin{array}{l}\text { Parameter } \\
\text { Estimates }\end{array}$ & $P$-Value \\
\hline FD & $-0.6485^{\star * *}$ & $<0.0001$ & $-0.6749^{* * *}$ & $<0.0001$ & $-0.6705^{\star * *}$ & $<0.0001$ \\
\hline CAGE & $0.0366^{\star * *}$ & 0.0003 & 0.0130 & 0.08182 & $0.0321^{* * *}$ & $<0.0001$ \\
\hline FAGE & $-0.08929^{* * *}$ & $<0.0001$ & $-0.1280^{\star * *}$ & $<0.0001$ & $-0.1131^{\star \star \star}$ & $<0.0001$ \\
\hline TNOVR & $1.4048^{\star * *}$ & $<0.0001$ & $1.7981^{\star * *}$ & 0.0001 & $1.2651^{\star * *}$ & $<0.0001$ \\
\hline FEE1 & $-14.1813^{\star * *}$ & $<0.0001$ & $-14.8354^{* \star \star}$ & $<0.0001$ & $-12.1518^{\star \star *}$ & $<0.0001$ \\
\hline FEE2 & $-8.2252^{\star * *}$ & $<0.0001$ & $-8.9844^{* * *}$ & $<0.0001$ & $-6.3728^{\star * *}$ & $<0.0001$ \\
\hline STARS1 & $0.1747^{\star *}$ & 0.0160 & $0.1879^{\star *}$ & 0.01479 & $0.1849^{* *}$ & 0.0116 \\
\hline STARB1 & $1.1919^{\star * \star}$ & $<0.0001$ & $1.1468^{\star \star \star}$ & $<0.0001$ & $1.1785^{\star * *}$ & $<0.0001$ \\
\hline CTMR2 & $1.5192^{\star * *}$ & $<0.0001$ & $1.6887^{* * *}$ & $<0.0001$ & $1.0389^{* * *}$ & $<0.0001$ \\
\hline CTMR1 & & & & & $0.3977^{\star * *}$ & $<0.0001$ \\
\hline F Value & 2110.02 & $<0.0001$ & & & & \\
\hline Adj. $R^{2}$ & 0.78 & & 0.8 & & 0.63 & \\
\hline
\end{tabular}

Symbols ${ }^{*},{ }^{* *}$, and ${ }^{* * *}$ represent rejection of the null hypothesis at the $10 \%, 5 \%$, and $1 \%$ significance levels. 
transaction costs and high administrative costs have adverse effects on raising the fund company's market share in the domestic-equity-fund and balancedfund markets. In terms of the impact of fund performance, the dummy variables STARS1 and STARB1 are significantly positive, which means that a fund company's asset scale and market share would be positively affected if the company holds domestic-equity funds ranked among the top 10 in performance or balanced funds ranked among the top 5 in performance. The number of customers subscribing to dollar-cost-averaging investment plans each month is also significantly positive ( 1.52 to 1.69 ), indicating that on average, if a fund company has a stable number of dollar-cost-averaging investment plan customers, it would have a positive effect on the fund company's asset scale and market share. Finally, the regression result of the average portfolio turnover rate shows a significantly positive effect on the market share of fund companies.

\section{Discussion and Conclusion}

This study uses funds from January 2001 to April 2013 as its data sample to examine whether or not a fund company being either domestic or foreign affects the company's market share. It also investigates how the fee expenses, the fund's management performance, and the constitution of the customer portfolio-e.g., the number of customers with dollar-cost-averaging investment plans-influence the asset scale and market share of the company's non-bond funds. We have some interesting findings, as follows. First, on average the market share of domestic fund companies was found to be higher than that of foreign fund companies. This could be due to the fact that the acquisitions made by foreign fund companies in recent years have been of domestic fund companies with smaller average asset sizes and market share. On the other hand, domestic fund companies with larger market shares were more reluctant to sell off because they had greater economies of scale and operational advantages. Second, the results of the regression analysis show that a star fund has a significantly positive impact on the market share of fund companies' non-bond funds. This is consistent with the previous literature on the spillover effect (see, e.g., [8] and [27]) and the flow-performance relation (see, e.g., [13] [16] [28] [29] [30]). Third, the results also showed that the number of customers with dollar-cost-averaging investment plans has a significantly positive impact on the market share of fund companies. Fourth, we found that the age of a fund within a company shows a significantly negative relation with market share, which implies that on average the company's oldest fund may not help enhance the company's market share. This result is consistent with the findings of [15] and [22]. Reference [15] finds that the convex flow-performance relation is more pronounced for younger funds. Reference [22] classifies young funds as high-value funds for fund families' favoritism strategies. Finally, fee expenses (transaction costs and management fees) are, on average, negatively sensitive to the market share of non-bond funds, which is consistent with the findings of [1], [5] and [31].

The empirical results of this paper show that fund companies committed to 
improving the performance of their funds can increase the market share of its non-bond funds based on the convex flow-performance relationship and the spillover effect reported in the previous literature. In addition, if fund companies can actively work to increase the number of customers with dollar-cost-averaging investment plans, this will also help to increase the scale of their assets under management. On the other hand, the results of the control variables in the analysis show that fund companies should be committed to lowering transaction costs and management fees in order to reduce the negative impact on market share.

This study is certainly not free from limitations. Some factors that might affect the scale of management assets and the market shares of fund companies may not be considered into the research model. To extend the analysis on different study periods can be possible direction for future studies.

\section{References}

[1] Barber, B., Odean, M.T. and Zheng, L. (2005) Out of Sight, Out of Mind: The Effects of Expenses on Mutual Fund Flows. The Journal of Business, 78, 2095-2120. https://doi.org/10.1086/497042

[2] Makadok, R. (1999) Interfirm Differences in Scale Economies and the Evolution of Market Shares. Strategic Management Journal, 20, 935-952.

https://doi.org/10.1002/(SICI)1097-0266(199910)20:10<935::AID-SMJ56>3.0.CO;2-G

[3] Khorana, A. and Servaes, H. (1999) The Determinants of Mutual Fund Starts. Review of Financial Studies, 12, 1043-1074. https://doi.org/10.1093/rfs/12.5.1043

[4] Pollet, J.M. and Wilson, M. (2008) How Does Size Affect Mutual Fund Behavior? Journal of Finance, 63, 2941-2969. https://doi.org/10.1111/j.1540-6261.2008.01417.x

[5] Khorana, A. and Servaes, H. (2012) What Drives Market Share in the Mutual Fund Industry? Review of Finance, 16, 81-113. https://doi.org/10.1093/rof/rfr027

[6] Spiegel, M. and Zhang, H. (2013) Mutual Fund Risk and Market Share-Adjusted Fund Flows. Journal of Financial Economics, 108, 506-528. https://doi.org/10.1016/j.jfineco.2012.05.018

[7] Collins, S. and Mack, P. (1997) The Optimal Amount of Assets under Management in the Mutual Fund Industry. Financial Analysts' Journal, 53, 67-73. https://doi.org/10.2469/faj.v53.n5.2119

[8] Shu, P.G., Yeh, Y.H. and Yamada, T. (2002) The Behavior of Taiwan Mutual Fund Investors-Performance and Fund Flows. Pacific-Basin Finance Journal, 10, 583 600. https://doi.org/10.1016/S0927-538X(02)00070-7

[9] Hsu, C.S. and Lin, J.R. (2007) Mutual Fund Performance and Persistence in Taiwan: A Non-Parametric Approach. The Service Industries Journal, 27, 509-523. https://doi.org/10.1080/02642060701411658

[10] Hung, W., Lu, C.C. and Lee, F. (2010) Mutual Fund Herding Its Impact on Stock Returns: Evidence from the Taiwan Stock Market. Pacific-Basin Finance Journal, 18, 477-493. https://doi.org/10.1016/j.pacfin.2010.06.001

[11] Brown, S. and Goetzmann, W.N. (1995) Performance Persistence. Journal of Finance, 50, 679-698. https://doi.org/10.1111/j.1540-6261.1995.tb04800.x

[12] Grinblatt, M., Titman, S. and Wermers, R. (1995) Momentum Investment Strategies Portfolio Performance and Herding: A Study of Mutual Fund Behavior. American Economic Review, 85, 1088-1105.

[13] Gruber, M. (1996) Another Puzzle: The Growth in Active Management of Mutual Funds. Journal of Finance, 51, 783-810. 
https://doi.org/10.1111/j.1540-6261.1996.tb02707.x

[14] Carhart, M.M. (1997) On Persistence in Mutual Fund Performance. Journal of Finance, 52, 57-82. https://doi.org/10.1111/j.1540-6261.1997.tb03808.x

[15] Chevalier, J. and Ellison, G. (1997) Risk Taking by Mutual Funds as a Response to Incentives. Journal of Political Economy, 105, 1167-1200. https://doi.org/10.1086/516389

[16] Sirri, E. and Tufano, P. (1998) Costly Search and Mutual Fund Flows. Journal of Finance, 53, 1589-1622. https://doi.org/10.1111/0022-1082.00066

[17] Wermers, R. (2000) Mutual Fund Performance: An Empirical Decomposition into Stock-Picking Talent, Style, Transaction Costs, and Expenses. Journal of Finance, 55, 1655-1695. https://doi.org/10.1111/0022-1082.00263

[18] Carhart, M.M., Kaniel, R., Musto, D. and Reed, D. (2002) Leaning for the Tape: Evidence of Gaming Behavior in Equity Mutual Funds. Journal of Finance, 57, 661693. https://doi.org/10.1111/1540-6261.00438

[19] Massa, M. (1998) Why so Many Mutual Funds? Mutual Fund Families, Market Segmentation and Financial Performance. Working Paper, INSEAD, New York.

[20] Massa, M. (2003) How Do Family Strategies Affect Fund Performance? When Performance Maximization Is Not the Only Game in Town. Journal of Financial Economics, 67, 249-304. https://doi.org/10.1016/S0304-405X(02)00253-2

[21] Nanda, V., Wang, Z.J. and Zheng, L. (2004) Family Values and the Star Phenomenon: Strategies of Mutual Fund Families. Review of Financial Studies, 17, 667-698. https://doi.org/10.1093/rfs/hhg054

[22] Gaspar, J.M., Massa, M. and Matos, P. (2006) Favoritism in Mutual Fund Families? Evidence on Strategic Cross-Fund Subsidization. Journal of Finance, 61, 73-104. https://doi.org/10.1111/j.1540-6261.2006.00830.x

[23] Huij, J. and Verbeek, M. (2007) Spillover Effects of Marketing in Mutual Fund Families. Working Paper, RSM Erasmus University, Rotterdam.

[24] Evans, R.B. (2010) Mutual Fund Incubation. Journal of Finance, 65, 1581-1611. https://doi.org/10.1111/j.1540-6261.2010.01579.x

[25] Brown, S., Goetzmann, W.N., Ibbotson R. and Ross, S. (1992) Survivorship Bias in Performance Studies. Review of Financial Studies, 5, 553-580. https://doi.org/10.1093/rfs/5.4.553

[26] Fama, E.F. and MacBeth, J. (1973) Risk Return and Equilibrium: Empirical Tests. Journal of Political Economy, 81, 607-636. https://doi.org/10.1086/260061

[27] Kempf, A. and Ruenzi, S. (2008) Family Matters: Rankings within Fund Families and Fund Inflows. Journal of Business Finance \& Accounting, 35, 177-199. https://doi.org/10.1111/j.1468-5957.2007.02062.x

[28] Ippolito, R.A. (1992) Consumer Reaction to Measures of Poor Quality: Evidence from the Mutual Fund Industry. Journal of Law and Economy, 35, 45-70. https://doi.org/10.1086/467244

[29] Goetzmann, W.N. and Peles, N. (1997) Cognitive Dissonance and Mutual Fund Investors. The Journal of Financial Research, 20, 145-158. https://doi.org/10.1111/j.1475-6803.1997.tb00241.x

[30] Del Guercio, D. and Tkac, P.A. (2002) The Determinants of the Row of Funds of Managed Portfolios: Mutual Funds versus Pension Funds. Journal of Financial and Quantitative Analysis, 37, 523-557. https://doi.org/10.2307/3595011

[31] Wilcox, R.T. (2003) Bargain Hunting or Star Gazing? Investors' Preferences for Stock Mutual Funds. Journal of Business, 76, 645-664.

https://doi.org/10.1086/377034 
Submit or recommend next manuscript to SCIRP and we will provide best service for you:

Accepting pre-submission inquiries through Email, Facebook, LinkedIn, Twitter, etc. A wide selection of journals (inclusive of 9 subjects, more than 200 journals)

Providing 24-hour high-quality service

User-friendly online submission system

Fair and swift peer-review system

Efficient typesetting and proofreading procedure

Display of the result of downloads and visits, as well as the number of cited articles Maximum dissemination of your research work

Submit your manuscript at: http://papersubmission.scirp.org/

Or contact tel@scirp.org 